\title{
Turning Voters on? Effects of News Frame Exposure on Voter Mobilization in the 2008 Austrian Elections
}

\section{Günther Lengauer* and Iris Höller}

Department of Political Science, University of Innsbruck, Austria

\section{Introduction}

Voter mobilization is not only "about how people approach elections; rather, it is mainly about how elections appear to people" [1]. Thereby, the appearance of elections to the electorate is critically coined by their portrayal in mass media as contemporary campaigns largely evolve as media events [2]. In this context, media exposure and its mobilizing impact on voters have increasingly been a matter of particular scientific attention [3,4], and Newton (1999) concluded with regard to the mobilization and media malaise theories that "it is not the form but the content of media, which matters" [5]

Thus, to refine the investigation of media exposure effects on mobilization in election campaigns, it seems fruitful to examine news framing effects, in particular, the impact of generic news frames [6]. Most recent research shows that not only the amount of coverage or the actor-related tone [4,7] and issue-related frames [8] but also generic news frames $[9,10]$ might have an impact on voter mobilization.

Every voter is exposed to different forms and levels of news framing, which are dependent on the individual set of media outlets he uses how frequently to gather political and electoral information. Each voter makes use of an individual set of media outlets (tabloid papers, commercial or public service TV news, etc.) to keep informed about electoral campaigns. Additionally, some voters draw on media coverage more habitually than others. This results in an individual set of news content exposure during campaigns-depending on which media outlets one uses how frequently. Hence, to examine convincing explanations of news exposure effects on political engagement, it seems insufficient to apply general media or news exposure measures or to differentiate between heavy broadsheet and tabloid users or to distinguish heavy newspaper readers from heavy television viewers. Additionally, it is necessary to measure actual media content parameters on the microlevel (news outlet related) and link them to the individual mix of news outlet exposure [10-12].

This study draws on an extensive content analysis of the newspaper and TV news coverage in the final six weeks of the 2008 Austrian election campaign and on a concerted post-election survey among Austrian voters. The instrument of binary logistic regressions allows us to test the extent to which the individual exposure to specific generic news frames is, in fact, a reliable predictor of voter mobilization. Thereby, we investigate the impact of news frame exposure on mobilization on two consecutive levels-the voters' cognitive (campaign attention) and behavioral engagement (voting turnout). By doing so, we propose a news framing framework containing two basic dimensions representing the levels of episodic game (episodic framing, game-centeredness) and confrontational negativity (conflict, negativity) that may affect the mobilization of the electorate to answer the guiding question: Does the exposure to episodic game and confrontational negativity in the news raise voters' engagement on the cognitive and behavioral level?

\section{Voter mobilization}

Referring to Norris (2006), who stated that the "use of communication channels is commonly regarded as most important for the process of mobilizing voters, particularly for generating attention and turnout" [13], we extract two cardinal dimensions of voter mobilization that may be critically affected by news frame exposure: (1) campaign attention on the cognitive engagement level and (2) voting turnout on the behavioral engagement level. In literature, attentiveness toward public affairs, politics, or the campaign is categorized as an indicator of cognitive engagement [14-16], whereas voting turnout refers to forms of behavioral engagement. Thereby, changes on the cognitive engagement level might be considered as being antecedent to changes regarding behavioral engagement, and thus, are more easily triggered. Consequently, we may also expect dissimilar effectiveness of news frame exposure on voter mobilization, dependent on whether it concerns changes of the cognitive or the behavioral engagement of voters.

\section{The predictors of voter mobilization}

When investigating reliable predictors of voter mobilization, the central question is "why people tune in or off politics" [17]. As voters are predominantly informed by the mass media about politics and elections, we suppose that their coverage may hold a significant impact on turning voters on or off politics. Evidently, the attention to the campaign or the likelihood of going to the polls is not exclusively driven by short-term, media-related parameters. Thus, coveragerelated indicators explaining voters' mobilization need to be embedded in a fundamental set of robust and reliable predictors, which reflect individual political orientations and socio demographic characteristics to put media-related factors in a larger explanatory context. Such a procedure helps to limit problems of endogeneity in media effect studies.

Previous research has identified a number of individual factors involved in stimulating campaign attention, interest, and voter turnout $[1,18,19]$, which are additionally linked to selective media use $[3,5]$. For example, Valentino, Beckmann and Buhr (2001) have shown in an experimental design that the strength of media exposure effects correlates with levels of sophistication or political involvement [20]. Among the reportedly most reliable predictors of voting turnout are sociodemographics of age, education or gender, and civic orientations such as political interest or party identification $[1,19,21]$. To establish a comprehensive research design, we extend the set of well-established

*Corresponding author: Günther Lengauer, Department of Political Science, University of Innsbruck, Austria, A-6020 Innsbruck, Tel: +43-512-507-38204; Fax: +43512-507-38299; E-mail: guenther.lengauer@uibk.ac.at

Received November 18, 2012; Accepted December 07, 2012; Published December 15, 2012

Citation: Lengauer G, Höller I (2012) Turning Voters on? Effects of News Frame Exposure on Voter Mobilization in the 2008 Austrian Elections. J Mass Commun Journalism 2:137. doi:10.4172/2165-7912.1000137

Copyright: (c) 2012 Lengauer G, et al. This is an open-access article distributed under the terms of the Creative Commons Attribution License, which permits unrestricted use, distribution, and reproduction in any medium, provided the original author and source are credited. 
predictors of voting turnout by variables capturing individual levels of news frame exposure. They are the center stage in our explanatory models of voting turnout and campaign attention to filter out the strength of explanatory power added by news framing exposure. With regard to voter mobilization in elections, earlier findings mostly refer to turnout as the central dependent variable. Measures regarding the attentiveness toward politics or the campaign are rather commonly applied as independent variables; however, they are only rarely utilized as the central dependent variables in explanatory models [13]. Here, we compare news framing effects on campaign attention and turnout to contrast the impact of identical news coverage stimuli on voter mobilization on the cognitive and on the behavioral levels.

To refine the search for news exposure effects on voters, we investigate the impact of exposure levels to specific news frames in the coverage instead of applying general news exposure measures. This is substantiated by Newton (1999) who noted with regard to effects of news on voter mobilization that "it seems to be the content of the media, rather than the form which is important" [5]. For several reasons, general news exposure might be a too cursory and fuzzy measure to provide accurate estimates of news exposure effects. First, measures of general media usage and exposure might be blurred by the avoidance of political news by the audiences in the first place. Second, contrasting levels of, for instance, TV, newspaper, or tabloid usage implies that such a distinction is sufficient to accordingly separate the content quality of the coverage along these lines. A sheer distinction of news outlets on the form level, however, might not always be accompanied by a respective distinction on the content level. It also suggests that most people exclusively use tabloid or quality news, television or newspapers, which is not the case, at least for the investigated Austrian case. People may be heavy TV and newspaper users or heavy public service TV news and tabloid paper users at the same time. Therefore, our approach relies on an integrative measure of individual exposure that controls for the usage of various news outlets with differing frequency that are coined by diverse forms and levels of news frames.

\section{Generic news frames}

To focus on specific news content, framing research offers a basic differentiation between issue-specific and generic frames [6]. Whereas issue frames are pertinent only to specific topics and debates, generic frames refer to the narrative quality of a news story by capturing its levels of episodic style, conflict, negativity or game-centeredness. The latter are at the focus of interest here, as they "transcend thematic limitations and can be identified in relation to different topics, some even over time and in different cultural contexts" $[6,22]$. This implies that generic frames are particularly applicable for investigating campaign coverage in its entirety and are not limited to specific issue debates or actors. Earlier research on effects of generic frames mainly focused on strategy or conflict framing as independent and political cynicism as the most common dependent variable and provided highly ambivalent empirical evidence $[12,20,23,24]$. Regarding conflict framing, Schuck et al. (2011) recently reported that exposure to conflict framing had a positive effect on the intention to vote in the 2009 European parliamentary elections [10]. Despite their ambiguity, earlier findings corroborate the notion that (1) exposure to generic frames may matter in terms of voter mobilization and that (2) different news frames may hold disparate effective power.

To refine the investigation of generic media framing effects, our analysis focuses on a concise but conclusive set of news frames to test its impact on voter mobilization. Our approach is based on generic frames that have been widely discussed, empirically validated, and appeared as prevalent characteristics of contemporary campaign coverage. Game framing [25-27], episodic framing [22], conflict framing [28-30], and negativity framing $[26,31]$ serve as our conceptual as well as analytical framework. We initially conducted a factor analysis to compute and outline the structural relationship and distinctiveness of the generic frames applied (Table 1).

The factor analysis reveals two rather distinct dimensions, each consisting of two of the applied generic frames. Factor 1 provides common activation levels of negativity and conflict and their antitheses in news reports. Derived from this, we label this factor as the level of confrontational negativity in news coverage. In contrast, Factor 2 shows that levels of game-centeredness and episodic framing extensively correspond in the news coverage, whereas the loading and activation of these generic frames is almost independent of the activation of the levels of negativity and conflict. As this factor represents the levels of incident- and game-centered, anecdotal, and de-contextualized reporting, we label this as the level of episodic game in electoral news. Factors 1 and 2 appear as distinct and complementary; however, they are still selective dimensions of electoral communication we will draw on in this news effect study. Now, we turn to these indicators in detail, which are applied to test the impact of the coverage on engaging the electorate.

\section{Episodic game in campaign news}

First, we turn to the game frame that is widely described as being a potential factor for attracting the audience [32], and thus, may also make people more attentive toward the campaign and engage voters [33]. It shares a great deal of common ground with the sometimes even changeably applied concepts of horse race framing [10] or strategy framing [12,23]. The area of overlap among these concepts, on which we focus here and which we label game framing, describes a portrayal of politics in a depoliticized way, lacking policy relevance and substance. Game-centered reporting is predominantly "structured around the notion that politics is a strategic game [in which] candidates compete for advantage" [25]. Thereby, politics is portrayed as a competitive game or horse race by mostly applying sports metaphors of winners and losers and their odds in the favor of voters and their target groups. The empirical evidence toward the effects of this form of media coverage with above-average audience appeal is highly ambivalent, which however might be partly due to inconsistencies in operationalizing the game, horse race, or strategy frame.

We define game framing as a device that primarily highlights the contest character of the election campaign in the form of horse race and contest metaphors. We hypothesize that game framing may primarily function as a mobilizing factor which does not only activate the contest notion but also may encourage voters to go to the polls by suggesting

\begin{tabular}{|l|c|c|}
\hline & Factor 1 & Factor 2 \\
\hline Game framing & .083 & .776 \\
\hline Episodic framing & -.038 & .785 \\
\hline Negativity framing & .818 & -.006 \\
\hline Conflict framing & .821 & .052 \\
\hline Factor label & Confrontational Negativity & Episodic Game \\
\hline
\end{tabular}

Note. Coded framing indexes are based on a tripartite Likert-scale each ranging from -1 to +1 (game: policy-centered vs. game-centered reporting; episodic: thematic vs. episodic framing; negativity: positive vs. negative tone; conflict: consensus vs. conflict). A value of 0 indicates that no pole is prevalent. Two components are extracted. Extraction method: Principal Component Analysis. Rotation method: Varimax with Kaiser Normalization. Rotation is converged in three iterations. Total cumulative variance explained (Eigenvalue above 1) by the factors is 64.3 percent. Table 1: Factor Analysis of Generic News Frames in the 2008 Austrian Election Coverage. 
that every single vote may make a difference. Additionally we base our hypothesis also on the reported heightened attractiveness of horse race reports [32].

Episodic framing is our second dimension indicating levels of episodic game in news coverage. This indicator mainly refers to the depiction of politics as decontextualized, fast-moving episodes and anecdotes [22]. Bennett (2009) refers to episodic framing as one of the four information biases that matter in contemporary political journalism by calling it "fragmentation" [34]. "As a result, the news generally comes to us in sketchy, dramatic capsules [34]." This depiction may foster the notion of immediacy, instancy and currentness, and thus, may also heighten the attentiveness and mobilization of voters.

To summarize, we assume that the more voters are exposed to the episodic game in the news, the more likely they perceive the campaign as entertaining, current, and contested and will consequently be more attentive toward the campaign (Hypothesis 1a) and more willing to turn out to vote (Hypothesis 2a). Thereby, we expect stronger effects on campaign attention than on voting turnout as changes regarding cognitive engagement occur more easily than changes regarding behavioral engagement.

\section{Confrontational negativity in campaign news}

Now we turn to the dimension of confrontational negativity, which displays references to conflict versus consent and good news versus bad news about politics. The level of negativity refers to the overall tone of the coverage and captures whether the story told is thought on the whole to be intersubjectively in the good news or bad news camp [26,35]. Thereby, indications of negativity are depictions of political failure, crisis, frustration, denial, neglect, deterioration, resignation, skepticism, threats, disappointment, or pessimistic views. The elevated appeal of negativity has been widely demonstrated in the field of cognitive psychology. People pay more attention and give more consideration to negative than to positive news [36]. The phenomenon that losses loom larger than gains is also documented for political psychology and political behavior [37,38]. Although earlier media content research repeatedly and empirically refer to the prevailing status of negative reporting of politics and election campaigns $[25,26]$, empirical evidence on the effect of negativity in the news on voters' cognitive and behavioral mobilization concentrates on actor-related tone and not on overall negativity $[4,7,39]$. Focusing on the US Senatorial race in 1990, Kahn and Kenney (1999) found that both the negativity of candidates' commercials and of the press coverage had a mobilizing impact on voting turnout [40]. Martin (2008) exemplarily showed for the 1974 US Presidential election that the proportion of negative stories in the news increased problem awareness as well as political interest [8]. By analogy to existing evidence on positive effects of negative campaign advertising on voting turnout [41-43], and in conjunction with the expectation that negative news attracts more attention, we assume that negative news functions as a voters' mobilizer.

The second indicator reflecting confrontational negativity is the level of conflict-centeredness. Whereas the overall tone can be interpreted as the non-directional form of negativity, conflict may be considered a directional form of negativity [35]. A news story is considered conflict-centered when references to controversies or conflicts are more prevalent than references to consensus and cooperation. Conflict-centered reporting relates to the depiction of disputes, controversies, disagreement, discordance or confrontation, whereas the consensus dimension captures portrayals of (potential) accordance, consonances, conformities, dispute settlements, agreement, willingness of cooperation, compromise and approval, or reconciliation [35]. Recent empirical research has impressively demonstrated that conflict is a dominant and vital news frame in contemporary political journalism [44]. De Vreese (2006) gives insights that the news focus on disagreement, conflict and diverging opinions and positions provides a form of mobilizing media content [45]. Controversy and conflict framing heat up the contest of political ideas and may boost the notion that something is at stake as positions apparently differ. Referring to effects of conflict framing, de Vreese and Tobiasen (2007) reported significant positive effects of exposure to news media that portrayed the European elections as a conflict-laden contest on turnout in the Danish 2004 EP elections [10,30].

To summarize, we consequently hypothesize that the more voters are exposed to confrontational negativity framing of politics in the news, the more likely they perceive the campaign as arousing and contested and will consequently be more attentive toward the campaign (Hypothesis 1b) and more willing to turn out to vote (Hypothesis 2b). Again, also in this dimension, we expect stronger effects on campaign attention than on voting turnout.

\section{Study Design and Methods}

This study concertedly applied an extensive content analysis of the political newspaper and TV coverage during the final six weeks of the 2008 Austrian election campaign as well as a representative post-election survey of 1,165 eligible voters. A well-documented problem of turnout questions in election surveys is over-reporting, resulting in a turnout bias [46]. As the surveyed turnout lies by 85.8 percent, our study only shows a moderate and acceptable level of over-reporting of 4.9 percentage points (80.9 percent of votes cast). The applied media content analysis comprised six major Austrian daily, national newspapers with the highest readership (Kronen Zeitung, Kleine Zeitung, Kurier, Österreich, Der Standard, Die Presse) and the two TV evening newscasts in the private and public service sector with the highest viewership (ATV Aktuell; ORF Zeit im Bild). The analysis (Sunday, August 17 to Saturday, September 27, 2008) included all news reports, interviews, editorials and letters to the editor on Austrian domestic and foreign politics. The selection criterion was exclusively topic-driven and no sectional restrictions were applied. The units of analysis and coding were the whole report. In total, 6,506 news items have been identified and coded (Kronen Zeitung $N=1,174$; Kleine Zeitung N=878; Kurier N=916; Österreich N=979; Der Standard N=1,063; Die Presse N=1,101; ATV Aktuell N=128; ORF Zeit im Bild $N=267)$. The validity test regarding the applied news frame variables showed an average researcher-coder concordance of 0.84 (Holsti). The Holsti measures for intercoder reliability varied from 0.72 (episodic), 0.76 (conflict), 0.77 (negativity) to 0.78 (game). These measures were established in a series of random sample-based pre- and retests. The media content analysis was conducted by the Media Analysis Team of AUTNES (Austrian National Election Study).

\section{Exposure measures}

Levels of game-centeredness, episodic reporting, conflict and negativity were each coded on a tripartite Likert-scale ranging from -1 (predominantly policy-centered/thematic/consensus-centered/positive in tone), 0 (ambivalent or not applicable) to +1 (predominantly gamecentered/episodic/conflict-centered/negative in tone). These absolute measures from -1 to +1 were the point of departure for establishing an integrative measure. First, regarding our news frame measures, we computed a simple index based on the dimensions extracted from 
the factor analysis. This resulted in a score for episodic game (mean of episodic and game scores per news item) and confrontational negativity (mean of conflict and negativity score per news story) ranging from -1 (low loading) to +1 (high loading). Then, the means per outlet of these scores were weighted by the individual exposure to this content. Thereby, the individual exposure to political news concerning the eight analyzed media outlets was compiled for each respondent and transferred into a score ranging from 0 (never) to 1 (on a daily basis). Weighting outlet-bound news frame scores with the respective individual exposure to this outlet results in a single and individual measure for the exposure to episodic game (episodic game exposure score-EGES), and confrontational negativity (confrontational negativity exposure score-CNES) (see calculation example in Table 5 in the Appendix).

\section{Hypothesis testing logic}

Starting from there, we computed binary logistic regression models with turnout (yes=1/no=0) and attention to the campaign (high=1/ low $=0$ ) as the dependent variables. Our modeling follows a stepwise procedure [19] to contrast the explanatory power added by exposure to different forms and levels of generic news framing. In our first and basic regression Model 1, we explain campaign attention (Table 3) and voting turnout (Table 4 ) by including sociodemographic characteristics as well as individual political predispositions only. Sociodemographic characteristics such age, gender, or education have long been known to affect voter mobilization [47-49] and media usage [5] likewise. Based on these insights, we include age, gender, and education in our basic explanatory model (see the Appendix for detailed descriptions and opertionalization).

Primarily following the social-psychological approach founded by Angus Campbell and colleagues (1960) and postulating that voting is primarily attitude driven [50], we identified political efficacy, interest in politics, satisfaction with democracy and trust in politics as central and crucial civic orientations in affecting voter mobilization [51,52]. Individual predispositions of voters relate to the psychological engagement and suggest that it does matter whether people care about politics. It is postulated that the higher the affirmative ties to the political system and politics, the higher the likelihood to pay attention to the campaign and to go to the polls. Inspired by the rational choice theorem [53], we also assume that people who think that their vote does make a difference are more likely to be more attentive and more likely to go to the polls. This notion is part of the concept of political efficacy, which strongly correlates with political participation [54-57]. Measures of political efficacy have also been repeatedly applied as independent variables when investigating media framing effects [58]. Besides perceptions of political efficacy, trust in politics appears to be another reliable indicator of affirmative civic orientations $[57,59,60]$. As van der Eijk and others have repeatedly argued that the meaning and importance of party identification measures in a European context is doubtful $[61,62]$, we draw on general interest in politics to additionally capture levels of political involvement. Interest in politics has evolved as a consistent determinant of voter mobilization $[55,57,63,64]$. "The more interested one is, the more likely one is to vote" [17]. In the style of Blais (2007), we postulate that those who have developed a constructive taste for politics may pay more attention to the campaign and are more likely to vote than those who have developed a destructive taste of politics [17]. As there exists a well-reported correlation between media usage and measures of political malaise and mobilization $[3,5]$, particularly regarding political interest, efficacy and trust, we implement these attitudes as central controls in our testing models, which are not severely affected by multicollinearity problems as all correlations among the applied socio-demographic and civic orientation variables were below .30 .

In the subsequent Models 2 and 3, we comparatively investigate to what extent specific media framing exposure scores (EGES and CNES) lead to an increase of the explanatory power of our regression models regarding campaign attention on the cognitive engagement level and voting turnout on the behavioral engagement level. In order to avoid multicollinearity problems regarding our measures of news frame exposure, we refrained from including these measures simultaneously, but rather contrast their effectiveness in separate models.

\section{Findings}

We start with the descriptive analysis of our media content analysis, as these data provide the foundation for our media effect models. As table 2 illustrates, we find clear levels (indicated by positive scores) of episodic game (.213) and confrontational negativity (.333) in the 2008 Austrian election coverage. In detail, political news in national newspapers and TV evening newscasts in the 2008 election campaign is distinctly dominated by an episodic focus instead of a contextualized, thematic focus (episodic score=.452). Non-directional negativity as well as conflict-centeredness clearly prevail over positive and consensus-centered framing (negativity score=.399; conflict score $=.267$ ). Thus, confrontational negativity is a dominant feature of campaign coverage in Austria in all investigated media outlets. So is episodic game framing. However, game framing is only prevalent in the tabloid papers Kronen Zeitung (game score=.004), Österreich (.229), and Kleine Zeitung (.007) as well as in the private TV newscast ATV Aktuell (game score=.313). In all other investigated media outlets, policy-centered reports outnumber game-centered ones. Whereas the prevalent levels of confrontational negativity are rather alike for all investigated news outlets, we find the lowest episodic game scores in the national quality press (Die Presse, Der Standard) and the public service TV news (ORF Zeit im Bild) and the highest scores in the tabloid papers Österreich, Kronen Zeitung, Kleine Zeitung and in the private TV newscast ATV Aktuell.

These outlined levels and differentiations along media outlets regarding episodic game and confrontational negativity in the Austrian news lay the ground for investigating their impact on campaign attention and voting turnout. Consequently, we build these reported framing scores into our survey measure of individual political news exposure in order to appropriately assess the impact of generic news framing in specific media outlets on the individual attentiveness

\begin{tabular}{|c|c|c|c|c|c|c|c|}
\hline \multirow{2}{*}{\multicolumn{2}{|c|}{$\begin{array}{l}\text { News Frame Scores } \\
(-1 \text { to }+1)\end{array}$}} & \multicolumn{3}{|c|}{ Episodic Game } & \multicolumn{3}{|c|}{ Confrontational Negativity } \\
\hline & & $\begin{array}{l}\text { Total } \\
\text { Score }\end{array}$ & $\begin{array}{l}\text { Game } \\
\text { Score }\end{array}$ & $\begin{array}{l}\text { Episodic } \\
\text { Score }\end{array}$ & $\begin{array}{l}\text { Total } \\
\text { Score }\end{array}$ & $\begin{array}{l}\text { Negativity } \\
\text { Score }\end{array}$ & $\begin{array}{l}\text { Conflict } \\
\text { Score }\end{array}$ \\
\hline \multicolumn{2}{|c|}{ All media outlets (total) } & .213 & -.026 & .452 & .333 & .399 & .267 \\
\hline \multirow{6}{*}{$\begin{array}{l}\text { News } \\
\text { papers }\end{array}$} & Kronen Zeitung & .314 & .004 & .623 & .407 & .500 & .318 \\
\hline & Österreich & .421 & .229 & .614 & .314 & .338 & .289 \\
\hline & Kurier & .205 & -.032 & .442 & .290 & .375 & .205 \\
\hline & Kleine Zeitung & .318 & .007 & .630 & .331 & .424 & .238 \\
\hline & Der Standard & .005 & -.198 & .208 & .326 & .378 & .274 \\
\hline & Die Presse & .047 & -.157 & .251 & .322 & .367 & .278 \\
\hline \multirow[t]{2}{*}{ TV news } & $\begin{array}{l}\text { ORF } \\
\text { Zeit im Bild }\end{array}$ & .122 & -.109 & .352 & .288 & .363 & .214 \\
\hline & ATV Aktuell & .395 & .313 & .477 & .375 & .523 & .227 \\
\hline
\end{tabular}

Table 2: Episodic Game and Confrontational Negativity in the 2008 Austrian Election Coverage. 
Citation: Lengauer G, Höller I (2012) Turning Voters on? Effects of News Frame Exposure on Voter Mobilization in the 2008 Austrian Elections. J Mass Commun Journalism 2:137. doi:10.4172/2165-7912.1000137

Page 5 of 8

toward the campaign and the likelihood to go to the polls. In table 3 , binary regression models, following a stepwise procedure and explaining campaign attention (dependent variable), are outlined. Model 1 represents a block of sociodemographics and individual civic orientations (independent variables) as a baseline control. Models 2 and 3 additionally consider individual news frame exposure levels regarding episodic game and confrontational negativity.

The basic predictors and controls in Model 1 explain 25 percent of the variance regarding campaign attention in the 2008 Austrian parliamentary elections (see Nagelkerke R-Square). The most influential and statistically significant predictors of campaign attention in this starting model are interest in politics and political efficacy which are positively correlated with the dependent variable. All other civic orientations and sociodemographics tested remain ineffective in reliably predicting campaign attention. These findings are substantiated by Drew and Weaver (2006), who reported for interest in the 2004 US election campaign that sociodemographics such as age, gender, or education were only weak predictors [18]. From Model 1 we can conclude that the more voters in Austria are interested in politics and the more they believe it does matter whom they vote for, the more they are attentive toward the campaign. This also holds true for our explanatory Models 2 and 3, additionally incorporating levels of news framing exposure. Thereby, in these extended models, the effect structure regarding sociodemographics and civic orientations

\begin{tabular}{|c|c|c|c|c|}
\hline \multirow{2}{*}{\multicolumn{2}{|c|}{$\begin{array}{l}\text { Dependent Variable: } \\
\text { Campaign Attention } \\
(1=\text { high; } 0=\text { low })\end{array}$}} & Model 1 & Model 2 & Model 3 \\
\hline & & $\begin{array}{c}\mathrm{B} \\
(\mathrm{SE})\end{array}$ & $\begin{array}{l}\mathrm{B} \\
(\mathrm{SE})\end{array}$ & $\begin{array}{c}\mathrm{B} \\
(\mathrm{SE})\end{array}$ \\
\hline \multirow{2}{*}{\multicolumn{2}{|c|}{ Constant }} & & & \\
\hline & & & & \\
\hline \multirow[t]{3}{*}{$\begin{array}{l}\text { Sociodemo- } \\
\text { graphics }\end{array}$} & Age & $\begin{array}{l}.006 \\
(.004) \\
1.006\end{array}$ & $\begin{array}{l}.007 \\
(.004) \\
1.007\end{array}$ & $\begin{array}{c}.006 \\
(.004) \\
1.006\end{array}$ \\
\hline & Gender & $\begin{array}{l}-.112 \\
(.140) \\
.894\end{array}$ & $\begin{array}{c}-.096 \\
(.141) \\
.908\end{array}$ & $\begin{array}{l}-.082 \\
(.141) \\
.921\end{array}$ \\
\hline & Education & $\begin{array}{c}-.003 \\
(.163) \\
.997\end{array}$ & $\begin{array}{c}.032 \\
(.163) \\
1.033\end{array}$ & $\begin{array}{l}-.031 \\
(.163) \\
.969\end{array}$ \\
\hline \multirow[t]{4}{*}{ Civic orientations } & $\begin{array}{l}\text { Political } \\
\text { Efficacy }\end{array}$ & $\begin{array}{l}.537^{* *} \\
(.171) \\
1.711\end{array}$ & $\begin{array}{l}.583^{* *} \\
(.173) \\
1.791\end{array}$ & $\begin{array}{l}.575^{\star *} \\
(.172) \\
1.777\end{array}$ \\
\hline & Interest in Politics & $\begin{array}{c}1.651^{* * *} \\
(.147) \\
5.210\end{array}$ & $\begin{array}{c}1.604^{* * *} \\
(.148) \\
4.975\end{array}$ & $\begin{array}{c}1.567^{* * *} \\
(.150) \\
4.792\end{array}$ \\
\hline & $\begin{array}{l}\text { Satisfaction with } \\
\text { Democracy }\end{array}$ & $\begin{array}{l}.198 \\
(.147) \\
1.219\end{array}$ & $\begin{array}{c}.226 \\
(.165) \\
1.254\end{array}$ & $\begin{array}{l}.220 \\
(.165) \\
1.245\end{array}$ \\
\hline & $\begin{array}{l}\text { Trust in } \\
\text { Politics }\end{array}$ & $\begin{array}{c}.248 \\
(.144) \\
1.281\end{array}$ & $\begin{array}{c}.226 \\
(.165) \\
1.254\end{array}$ & $\begin{array}{l}.220 \\
(.165) \\
1.245\end{array}$ \\
\hline \multirow[t]{2}{*}{$\begin{array}{l}\text { News } \\
\text { frame exposure }\end{array}$} & $\begin{array}{l}\text { Episodic Game } \\
\text { Exposure (EGES) }\end{array}$ & & $\begin{array}{l}.705^{*} \\
(.275) \\
2.024\end{array}$ & \\
\hline & $\begin{array}{l}\text { Confrontational Negativity } \\
\text { Exposure (CNES) }\end{array}$ & & & $\begin{array}{l}.676^{* *} \\
(.228) \\
1.966\end{array}$ \\
\hline \multicolumn{2}{|c|}{ Adjusted $R^{2}$ (Nagelkerke) } & .252 & .259 & .261 \\
\hline \multicolumn{2}{|l|}{ Incremental $R^{2}$} & & $+0.7 \%^{*}$ & $+0.9 \%$ ** \\
\hline \multicolumn{2}{|c|}{ Log Restricted-Likelihood } & 1252.896 & 1246.317 & 1244.090 \\
\hline \multicolumn{2}{|c|}{ Number of valid cases } & 1,066 & 1,066 & 1,066 \\
\hline
\end{tabular}

Note: ${ }^{* * *} p<0.001 ;{ }^{* *} p<0.01,{ }^{*} p<0.05$.

Table 3: Binary Logistic Regressions Explaining News Frame Exposure Effects on Campaign Attention.

\begin{tabular}{|c|c|c|c|c|}
\hline \multirow{2}{*}{\multicolumn{2}{|c|}{$\begin{array}{l}\text { Dependent Variable: } \\
\text { Voting Turnout - yes (1), no (0) }\end{array}$}} & Model 1 & Model 2 & Model 3 \\
\hline & & & & \\
\hline \multirow{2}{*}{\multicolumn{2}{|c|}{ Constant }} & & & \\
\hline & & -300 & -.582 & $\begin{array}{l}-.786 \\
(421)\end{array}$ \\
\hline \multirow{4}{*}{$\begin{array}{l}\text { Sociodemo- } \\
\text { graphics }\end{array}$} & & & & \\
\hline & Age & $\begin{array}{l}.011^{*} \\
(.006) \\
1.011\end{array}$ & $\begin{array}{l}.012^{*} \\
(.006) \\
1.012\end{array}$ & $\begin{array}{l}.012^{*} \\
(.006) \\
1.012\end{array}$ \\
\hline & Gender & $\begin{array}{c}-.054 \\
(.209) \\
.947\end{array}$ & $\begin{array}{c}-.049 \\
(.209) \\
.953\end{array}$ & $\begin{array}{c}-.036 \\
(.209) \\
.964\end{array}$ \\
\hline & Education & $\begin{array}{c}-.066 \\
(.254) \\
.936\end{array}$ & $\begin{array}{c}-.061 \\
(.255) \\
.941\end{array}$ & $\begin{array}{c}-.123 \\
(.256) \\
.884\end{array}$ \\
\hline \multirow[t]{4}{*}{ Civic orientations } & $\begin{array}{l}\text { Political } \\
\text { Efficacy }\end{array}$ & $\begin{array}{c}1.136^{\star * \star} \\
(.206) \\
3.113\end{array}$ & $\begin{array}{c}1.171^{* * *} \\
(.208) \\
3,226\end{array}$ & $\begin{array}{c}1.191^{* * *} \\
(.209) \\
3.289\end{array}$ \\
\hline & Interest in Politics & $\begin{array}{c}1.416^{* * *} \\
(.285) \\
4.119\end{array}$ & $\begin{array}{c}1.393^{* * *} \\
(.286) \\
4.029\end{array}$ & $\begin{array}{c}1.345^{\star \star \star} \\
(.287) \\
3.837\end{array}$ \\
\hline & $\begin{array}{l}\text { Satisfaction } \\
\text { with Democracy }\end{array}$ & $\begin{array}{l}.418^{*} \\
(.212) \\
1.519\end{array}$ & $\begin{array}{l}.419^{\star} \\
(.213) \\
1.520\end{array}$ & $\begin{array}{l}.419^{*} \\
(.213) \\
1.520\end{array}$ \\
\hline & $\begin{array}{l}\text { Trust in } \\
\text { Politics }\end{array}$ & $\begin{array}{l}.863^{\star \star *} \\
(.220) \\
2.370\end{array}$ & $\begin{array}{l}.852^{\star * *} \\
(.221) \\
2.344\end{array}$ & $\begin{array}{l}.841^{* * *} \\
(.221) \\
2.319\end{array}$ \\
\hline \multirow[t]{2}{*}{$\begin{array}{l}\text { News } \\
\text { frame exposure }\end{array}$} & $\begin{array}{l}\text { Episodic Game } \\
\text { Exposure } \\
\text { (EGES) }\end{array}$ & & $\begin{array}{c}.519 \\
(.393) \\
1.681\end{array}$ & \\
\hline & $\begin{array}{l}\text { Confrontational } \\
\text { Negativity } \\
\text { Exposure (CNES) }\end{array}$ & & & $\begin{array}{l}.762^{*} \\
(.337) \\
2.142\end{array}$ \\
\hline \multicolumn{2}{|c|}{ Adjusted $R^{2}$ (Nagelkerke) } & .229 & .231 & .237 \\
\hline \multicolumn{2}{|l|}{ Incremental $R^{2}$} & & $+0.2 \%$ & $+0.8 * \%$ \\
\hline \multicolumn{2}{|c|}{ Log Restricted-Likelihood } & 656.881 & 655.107 & 651.584 \\
\hline \multicolumn{2}{|c|}{ Number of valid cases } & 1,060 & 1,060 & 1,060 \\
\hline
\end{tabular}

Note: ${ }^{* * *} p<0.001 ;{ }^{* *} p<0.01,{ }^{*} p<0.05$.

Table 4: Binary Logistic Regressions Explaining News Frame Exposure Effects on Voting Turnout.

remains unaltered and robust. However, additionally, we find news frame exposure to episodic game and confrontational negativity to be positively associated with campaign attention. Model 2 outlines that exposure to different levels of episodic game framing holds a significant impact on the attention devoted to the campaign. Austrian voters are sensitive to news impulses of episodic game-centered reporting when it comes to their attentiveness toward the campaign. By adding episodic game exposure to our regression model, the explanatory power increases significantly by 0.7 percent. This means that 0.7 percent of the variance regarding campaign attention in the Austrian electorate is explained by episodic game exposure in the news. Thus, Hypothesis 1a, postulating that exposure to episodic game framing increases the attention toward the campaign, is supported by our data.

Similarly, Model 3 shows that exposure levels regarding confrontational negativity may also impact the attention that is devoted to the campaign. The explanatory power of this model also increases slightly, but is still statistically significant, by 0.9 percent. Consequently, Hypothesis $1 \mathrm{~b}$, expecting that exposure to confrontational negativity positively stimulates the attentiveness to the campaign, is supported by our findings.

To summarize, regarding the cognitive engagement of voters, we find that both episodic game and confrontational negativity framing hold a positive impact on the attentiveness toward the campaign. 
Anecdotal, entertaining episodes, negativity, and controversies in the news obviously stimulate the attention of Austrian voters toward the campaign.

Having outlined the effects of news framing exposure on cognitive engagement, we now turn to potential news exposure effects on behavioral engagement and look at the predictors of voting turnout in the 2008 Austrian national elections (Table 4). Again, our starting binary regression Model 1 comprises sociodemographic characteristics and individual civic orientations only. It accounts for about 23 percent of the variance in voting turnout in Austria in 2008. Similar to campaign attention, the most influential (positive) predictors of voting turnout in this analytical framework are interest in politics and political efficacy, however on this behavioral level supplemented by satisfaction with democracy and trust in politics. A slight positive effect is also shown for age. The older Austrian voters are and the more a constructive taste on politics they develop, the more they are willing to cast their vote. To now expand our view to the potential effects added by news framing exposure, we turn to the extended regression Models 2 to 3.

Again, we turn our focus to the framing of politics along the dimensions of episodic game and confrontational negativity. Model 2, adding individual exposure levels to episodic game in the news, shows that it is not associated with voting turnout in Austria. The framing of politics as an anecdotal horse races and episodic incidents does not mobilize Austrian voters on the behavioral level. Episodic game framing remains effective on the level of cognitive engagement and stimulate the attentiveness of Austrian voters to the campaign, but does not bring about a change on the behavioral level as far as voter mobilization is concerned. Therefore, in this regard, Hypothesis $2 \mathrm{a}$, postulating a positive relationship between exposure to episodic game framing in the news and voting turnout, is not supported. These findings are partially corroborated by Schuck et al. (2011), who recently found no turnout effect of horse race news framing on European elections and who concluded that horse race coverage may not offer a substantive basis to successfully engage voters on the behavioral level [10].

In contrast, the second dimension of confrontational negativity reveals a significant positive impact on voting turnout (see Model 3). Exposure to confrontational and negative news on politics not only raises campaign attention but also mobilizes voters on the behavioral level. Hypothesis $2 b$, assuming that high exposure to confrontational negativity would bring about higher levels of turnout, is moderately supported for the Austrian context. The explanatory power of this model is raised by 0.8 percent when incorporating exposure levels of confrontational negativity in the news. This means that almost one per cent of the variance in voting turnout can be explained by the exposure to confrontational negativity in the news.

Taking the results referring to campaign attention and voting turnout together, we find clear indications that exposure to confrontational negativity in the news, measured as levels of conflict and negativity, mobilizes Austrian voters on the level of cognitive engagement (regarding campaign attention) as well as on the level of behavioral engagement (regarding turnout). The more negative and conflict-centered the coverage and the higher the exposure to this news content, the more people pay attention and the more they are willing to actually go to the polls. The media stimulus of confrontational negativity is effective on both mobilization levels. In contrast, stimuli concerning episodic game framing by the media are effective with regard to campaign attention but are turning effectless when it comes to voter mobilization on the behavioral level. As expected, the effects of generic news framing regarding confrontational negativity and episodic game are, in total, stronger with regard to cognitive engagement than to behavioral engagement.

\section{Conclusion and Discussion}

The present study investigated effects of exposure to generic news frames on the mobilization of the electorate in the 2008 Austrian parliamentary elections on two levels: the cognitive and the behavioral engagement. We hypothesized that episodic game and confrontational negativity framing would rather engage voters than turning them off by connoting closeness, relevance, and currentness when emphasizing that the campaign is entertaining, arousing, negative, and contested. We find that exposure to news framing matters and media coverage may be a mobilizer, however, it may hold variable effects on different levels of persuasion. Confrontational negativity in the news turns out to be a rather unrestricted mobilizer that is effective on the cognitive and behavioral level of voter engagement, whereas episodic game in the news appears as a rather restricted mobilizer, being only effective in cognitive engagement.

These results hold some relevant implications for political and electoral communication. We may conclude that framing campaigns as confrontational and negative may work not only for the media to attract audience but also for democracy as it stimulates voters on different activation levels. On the other hand, media framing regarding episodic game may also work for the media to maximize their audiences [32], however, these framing strategies do not universally work for democracy as they do not prompt voters to actually go to the polls.

Our study enhances empirical evidence on news effects by applying integrative, exposure-weighted, and content-related measures. By doing so, we gain more reliable estimates of news content exposure, as we measure actual media content parameters on the micro-level (news outlet related) and link them to their individual exposure. Such a procedure regards the individual exposure to a mix of news outlets and different kinds and levels of news framing exerted by different news outlets.

Our study is, however, characterized by some limitations. It has a static analytical focus and is not able to depict changes of the propensity to vote and of the attention that is devoted to the campaign over time. Consequently, this cross-sectional study design does not allow us to entirely resolve the issue of causality with regard to news framing effects on voter mobilization. Further research on episodic game framing and confrontational negativity in the news should apply dynamic panel designs to enhance the focus on changes over time.

\section{Acknowledgment-Funding}

This work was supported by the Austrian National Election Study (AUTNES) a National Research Network sponsored by the Austrian Research Fund (FWF (Project: Lengauer-Media Coverage and Effects, S10904-G11). The authors thank the Student Assistant Team consisting of Franz-Josef Brettermeier, Elisabeth Grohsmann, Lea Hetfleisch, Manuel Innerhofer, Marlene Lackner, Juliane Nagiller Edina Nozinovic, Mathias Rentzsch, Matthias Sauermann, and Jürgen Vonbank for collecting and coding the media content analysis data.

\section{Appendix}

Calculation Example for the Individual Episodic Game Exposure Score (GES)

Voter A read the Kronen Zeitung on a daily basis (score 1), Österreich only rarely (score 0.33 ), Kurier also only rarely (score 0.33 ), Kleine Zeitung neve (score 0), Der Standard never (score 0), and Die Presse never (score 0). Voter A additionally viewed ORF Zeit im Bild on a daily basis (score 1) and ATV Aktuell rarely (score 0.33 ). These individual outlet exposure scores were weighted with and thus, multiplied by the news outlet specific episodic game scores displayed in table 2. The sum of these weighted scores results in the individual episodic game exposure score (EGES), which is +.768 for Voter $A$ (Table 5 ). This individual 
Citation: Lengauer G, Höller I (2012) Turning Voters on? Effects of News Frame Exposure on Voter Mobilization in the 2008 Austrian Elections. J Mass Commun Journalism 2:137. doi:10.4172/2165-7912.1000137

episodic game exposure score is then integrated into the post-election survey data set, which builds the basis for all regression analyses, explaining news exposure effects on voting turnout and campaign attention.

\begin{tabular}{|l|l|c|c|c|}
\hline Voter A & Media Outlet & $\begin{array}{c}\text { Outlet-Specific } \\
\text { Episodic Game } \\
\text { Score }\end{array}$ & $\begin{array}{c}\text { Individual } \\
\text { Outlet } \\
\text { Exposure }\end{array}$ & $\begin{array}{c}\text { Episodic Game } \\
\text { Exposure Score } \\
\text { Addends }\end{array}$ \\
\hline & Kronen Zeitung & .314 & 1 & $.314 \times 1=+.314$ \\
\hline & Österreich & .421 & .33 & $.421 \times .33=+.139$ \\
\hline Kurier & .205 & .33 & $.205 \times .33=+.062$ \\
\hline Kleine Zeitung & .318 & 0 & $.318 \times 0=.000$ \\
\hline Der Standard & .005 & 0 & $.005 \times 0=.000$ \\
\hline & Die Presse & .047 & 0 & $.047 \times 0=.000$ \\
\hline & ORF Zeit im Bild & .122 & 1 & $.122 \times 1=+.122$ \\
\cline { 2 - 5 } & ATV Aktuell & .395 & .33 & $.395 \times .33=+.131$ \\
\hline
\end{tabular}

Table 5: Calculation Example for Episodic Game Exposure Score (EGES)

Overview of Survey Variables

Turnout: Variable indicating if respondent voted; $1=y e s, 0=$ no; Campaign Attention: A 4-point scale recoded into two categories indicating how attentive the respondents were toward the campaign; $1=$ very attentive, $0=$ not at all attentive; Age: measured in years; Gender: male $=1$; female $=0$; Education: Multi-item nominal scale dichotomized in "A level education or university degrees" (1) and "lower education levels" (0); Political efficacy: A single-item indicating whether people think who they vote for makes a difference or not reaching from 1 (makes a big difference) to 5 (doesn't make any difference). Dichotomized to 1 (makes a difference) and 0 (makes no difference); Interest in politics: A 5-item question ranging from 1 (very high interest) to 5 (no interest). Dichotomized in 1 (high) and 0 (low); Satisfaction with democracy: A single item indicating how satisfied respondents are with how democracy works in Austria ranging from 1 (very satisfied) to 4 (very unsatisfied). Recoded into a two-dimensional measure of satisfaction with democracy (satisfied=1; unsatisfied=0); Trust in politics: A 4-item trust index containing levels of trust toward the national parliament, the government, political parties and politicians reaching from 1 (no trust at all) to 11 (complete trust). Dichotomized in 1 (high trust) and 0 (low trust)

\section{References}

1. Franklin MN (2004) Voter turnout and the dynamics of electoral competition in established democracies since 1945. Cambridge University Press, Cambridge.

2. Dalton RJ (2002) Citizen politics: Public opinion and political parties in advanced industrial democracies. Chatham House, New York: 352.

3. Arts K, Semetko HA (2003) The divided electorate: Media use and political involvement. Journal of Politics 65: 759-784

4. Norris P (2000) A Virtuous circle? Political communications in post industria societies. Cambridge University Press, New York.

5. Newton K (1999) Mass media effects: Mobilization or media malaise? British Journal of Political Science 29: 577-599.

6. Vreese de $\mathrm{CH}$ (2005a) News framing: Theory and typology. Information Design Journal + Document Design 13: 51-62.

7. Sanders D, Norris $P$ (1997) Does negative news matter? The effect of television news on party images in the 1997 British general election. Journal of Elections Public Opinion \& Parties 8: 150-170.

8. Martin PS (2008) The mass media as sentinel: Why bad news about issues is good news for participation. Political Communication 25: 180-193.

9. Adriaansen ML, Van Praag P, De Vreese C (2010) Substance matters: how news content can reduce political cynicism. Int J Public Opin Res 22: 433-457.

10. Schuck A, Vliegenthart R, Vreese de CH (2011) Who's afraid of conflict? How conflict framing in campaign news coverage mobilized voters in the 2009 European parliamentary elections. Paper presented at the annual meeting of the International Communication Association (ICA), Boston, USA.

11. Slater MD (2004) Operationalizing and analyzing exposure: The foundation of media effects research. Journalism \& Mass Communication Quarterly 81: 168183

12. Elenbaas $\mathrm{M}$, Vreese de $\mathrm{CH}$ (2008) The effects of strategic news on political cynicism and vote choice among young voters. Journal of Communication 58 : $550-567$
13. Norris P (2006) Did the media matter? Agenda-setting, persuasion and mobilization effects in the British general election campaign. British Politics 1 : 195-221.

14. Zaller J (1992) The nature of origins of mass opinion. Cambridge University Press, Cambridge.

15. Zukin C, Keeter S, Andolina M, Jenkins K, Delli Carpini M (2006) A new engagement? Political Participation, Civic Life, and the Changing American Citizen, Oxford University Press, Oxford.

16. Delli Carpini MX (2004) Mediating democratic engagement: The impact of communications on citizens' involvement in political and civic life. In Kaid LL (Ed.) Handbook of Political Communication Research. Lawrence Erlbaum Mahwah: 39.

17. Blais A (2007) Turnout in elections. In Dalton RJ, Klingemann H-D (Eds.) The Oxford handbook of political behavior. Oxford University Press, Oxford.

18. Drew D, Weaver D (2006) Voter learning in the 2004 Presidential election: Did the media matter? Journalism \& Mass Communication Quarterly 83: 25-42.

19. Seeber G, Steinbrecher M (2011) Why Europeans (don't) turnout to vote. In Maier M, Strömbäck J, Kaid LL (Eds.) Political communication in European parliamentary elections. Ashgate, Farnham.

20. Valentino NA, Beckmann MN, Buhr TA (2001) A spiral of cynicism for some: The contingent effects of campaign news frames on participation and confidence in government. Political Communication 18: 347-367.

21. Norris P (2004) Electoral engineering: Voting rules and political behavior Cambridge University Press, New York.

22. Iyengar S (1991) Is anyone responsible? How television frames political issues. The University of Chicago Press, Chicago: 206.

23. Cappella J, Jamieson KH (1997) Spiral of cynicism: The press and the public good. Oxford University Press, Oxford.

24. Vreese de $\mathrm{CH}$ (2005b) The spiral of cynicism reconsidered. European Journal of Communication 20: 283-301.

25. Patterson TE (1993) Out of order. Vintage, New York.

26. Patterson TE (2000) Doing well and doing good: How soft news and critical journalism are shrinking the news audience and weakening democracy - and what news outlets can do about it. Joan Shorenstein Center, Harvard University.

27. Lawrence RG (2001) Game-framing the issues: Tracking the strategy frame in public policy news. Political Communication 17: 93-114.

28. Neuman WR, Just MR, Crigler AN (1992) Common knowledge. News and the construction of political meaning. University of Chicago Press, Chicago.

29. Semetko HA, Valkenburg PM (2000) Framing European politics: A conten analysis of press and television news. Journal of Communication 50: 93-109.

30. Vreese de $\mathrm{CH}$, Tobiasen M (2007) Conflict and identity: Explaining turnout and anti-integrationist voting in the Danish 2004 elections for the European parliament. Scandinavian Political Studies 30: 87-114.

31. Benson R, Hallin DC (2007) How states, markets and globalization shape the news: The French and U.S. national press, 1965-1997. European Journal of Communication 22: 27-48.

32. lyengar S, Norpoth $\mathrm{H}$, Hahn KS (2004) Consumer demand for election news: The horserace sells. The Journal of Politics 66: 157-175.

33. Johansson B ( 2006) Does campaign coverage improve as election day approaches? Paper presented at the annual meeting of the International Communication Association (ICA), Dresden, Germany.

34. Bennett LW (2009) News. The politics of illusion. Pearson Longman, New York: 216.

35. Lengauer G, Esser F, Berganza R (2012) Negativity in political news. A review of concepts, operationalizations and key findings. Journalism 13: 179-202.

36. Mutz D, Reeves B (2005) The new videomalaise: Effects of televised incivility on political trust. American Political Science Review 99: 1-15.

37. Althaus SL, Kim YM (2006) Priming effects in complex information environments: Reassessing the impact of news discourse on presidential approval. Journal of Politics 68: 960-976. 
Citation: Lengauer G, Höller I (2012) Turning Voters on? Effects of News Frame Exposure on Voter Mobilization in the 2008 Austrian Elections. J Mass Commun Journalism 2:137. doi:10.4172/2165-7912.1000137

38. Lau, RR (1985) Two explanations for negativity effects in political behavior. American Journal of Political Science 29: 119-138.

39. Kleinnijenhuis J, Hoof van AM, Oegema D (2006) Negative news and the sleeper effect of distrust. The Harvard International Journal of Press/Politics 11: 86-104.

40. Kahn KF, Kenney PJ (1999) Do negative campaigns mobilize or suppress turnout? Clarifying the relationship between negativity and participation. The American Political Science Review 93:877-889.

41. Freedman P, Goldstein K (1999) Measuring media exposure and the effects of negative campaign ads. American Journal of Political Science 43: 1189-1208.

42. Goldstein K, Freedman $P$ (2002) Campaign advertising and voter turnout: New evidence for a stimulation effect. Journal of Politics 64: 721-740.

43. Wattenberg MP, Brians CL (1999) Negative campaign advertising: Demobilizer or mobilizer? American Political Science Review 93: 891-899.

44. Vliegenthart R, Boomgaarden HG, Boumans J (2011) Changes in political news coverage: Personalization, conflict and negativity in British and Dutch newspapers. In Brants K, Voltmer K (Eds.) Political communication in postmodern democracy. Challenging the primacy of politics. Palgrave Macmillan: Hampshire.

45. Vreese de $\mathrm{CH}$ (2006) Political parties in dire straits? Consequences of national referendums for political parties. Party Politics 12: 581-598.

46. Duff B, Hanmer MJ, Park WH, White IK (2007) Good excuses: Understanding who votes with an improved turnout question. Public Opinion Quarterly 71: 6790.

47. Blais A (2000) To vote or not to vote? The merits and limits of rational choice. University of Pittsburgh Press, Pittsburgh: 200.

48. Lazarsfeld PF, Berelson BR, Gaudet H (1944) The people's choice. How the Voter Makes Up His Mind in a Presidential Campaign.Columbia University Press, New York

49. Wolfinger R, Rosenstone S (1980) Who votes? Yale University Press, New Haven.

50. Campbell A, Converse E, Miller WE, Stokes, DE (1960) The American voter. University of Chicago Press, Chicago: 576.
51. Aldrich JH, Simon DM (1986) Turnout in american national elections. In Long S (Ed.) Research in micropolitics. JAI Press, Greenwich, Conneticut.

52. Campbell A, Gurin G, Miller WE (1954) The voter decides. Row, Peterson and Company, Evanston, Illinois: 242.

53. Downs A (1957) An economic theory of democracy. Harper \& Brothers, New York.

54. Almond G, Verba S (1963) The civic culture: Political attitudes and democracy in five nations. Sage publication, Newbury Park, CA: 392.

55. Powell GB (1986) American voter turnout in comparative perspective. The American Political Science Review 80: 17-43.

56. Rosenstone SJ, Hansen JM (1993) Mobilization, participation and democracy in America. Macmillan, New York.

57. Shaffer SD (1981) A multivariate explanation of decreasing turnout in presidential elections, 1960-1976. American Journal of Political Science 25 68-95.

58. Vreese de $\mathrm{CH}$, Semetko HA (2002) Cynical and engaged. Strategic campaign coverage, public opinion, and mobilization in a referendum. Communication Research 29: 615-641.

59. Cox M (2003) When trust matters: Explaining differences in voter turnout. JCMS: Journal of Common Market Studies 41: 757-770.

60. Grönlund K, Setälä M (2007) Political trust, satisfaction and voter turnout. Comparative European Politics 5: 400-422.

61. Eijk van der C, Franklin MM (1996) Choosing Europe? The European electorate and national politics in the face of the Union. University of Michigan Press, Ann Arbor: 516.

62. Eijk van der C, Niemöller B (1983) Electoral change in the Netherlands: Empirical results and methods of measurement. CT Press, Amsterdam.

63. Caballero C (2005) Nichtwahl. In FalterJW, Schoen H (Eds.) Handbuch Wahlforschung. VS Verlag für Sozialwissenschaften, Wiesbaden.

64. Verba S, Schlozman K, Brady H (1995) Voice and equality: Civic voluntarism in American politics. Harvard University Press, Cambridge, Massachusetts. 